\title{
THE IMPROVEMENT OF BEPANG CAKE PRODUCTION QUALITY BY AN INDEPENDENT INSTITUTION THAT WORKS ON THE COMMUNITY (LM3)
}

\author{
Grace. F. E. Suoth; Maxi Tendean \\ Universitas Negeri Manado \\ gracesuothgrace@gmail.com, maxitendean@gmail.com
}

\begin{abstract}
Abstrak
The Community Service program entitled The Improvement of Bepang Cake Quality Production and Marketing is focused on 4 main activities, namely (1) counseling on institutional strengthening and group members as partners, (2) counseling on dialogue strategies to equalize perceptions, (3) training on management map preparation Bepang cake product development problems, and (4) training on the preparation of a roadmap for the management of problems developing Bepang cake products in order to improve product quality. These activities are aimed at (1) identifying and managing problems related to institutions and partner group members, (2) providing knowledge / insights about common perceptions strategies, in order to reach an agreement between institutional leaders and members regarding the management of institutional problems and members. , as well as improving the quality and marketing of Bepang cakes, (3) providing knowledge / insights to partners on how to manage group problems, in the form of problem management maps, and (4) roadmaps for implementing institutional and member strengthening programs, as well as quality improvement programs. and product marketing to provide clear directions for program implementation, carry out assistance, monitor and evaluate work processes and results. The final goal is to empower members of partner organizations / groups to resume business, improve the quality of production and marketing of Bepang cakes. Specific targets are (1) the spirit of group members' efforts to revive, (2) quality products, (3) varied flavors, (4) attractive packaging, (5) favorable prices, (6) independence and responsibility in doing business. . The method used is the lecture method, participatory method. The results are as follows: Phase I, institutional strengthening of group members (LM3) through counseling activities on management systems, training as a basis for being able to produce outputs as intellectual property rights how to seek innovations to increase the quality of Bepang cake production, including Industrial product design (draft) so that it is feasible to sell at a higher price and how to independently break through the accessibility of marketing at the national, even global level. The second stage is evaluating the results of work in developing the processing of Cakes Bepang products that are of higher quality and accompanying the search for marketing accessibility. The 3rd stage, improving the quality of Industrial product design technology, so that it is feasible to sell at a higher price and how to independently break through better marketing accessibility at the national and global levels
\end{abstract}

Keywords: Bepang cake, institutional strengthening and members, improvement of the quality of production, community empowerment, independent attitude. 


\section{PREFACE}

\section{Situation Analysis}

The rice commodity is one of the priority commodities that plays an important role because it is the staple food of the population. This commodity is based on the spatial distribution of farming, relatively evenly distributed in the four districts of Langowan. (BPS Kabupaten Minahasa, 2012; Suoth G.F.E.,Profil Kota Langowan, 2015). The trend level of demand for rice commodity is quite promising when viewed from the existing market opportunities. In addition to local markets, rice commodity marketing areas are also in the traditional markets of Tomohon city, Manado, Bitung and other areas. Efforts to improve the income of the farming community through increasing productivity and applying science and technology for superior agricultural products, namely rice, are marked by an increase in their added value. The added value factor that supports the development of a variety of snack foods industry sector using rice as raw material, including "Bepang Cake". Bepang cake is a home industry product, which is known as a typical snack in the Langowan area and its surroundings, because of its crunchy, sweet and savory taste. "Kue Bepang Karondoran" is one of the products of home industry that is well known in this area. In fact, this cake is in great demand by Minahasa, Manado and Bitung people who have lived permanently outside the region, such as Jakarta and other areas. , those who live abroad, such as the United States, the Netherlands, Japan and Singapore. If there are holidays and holidays such as Christmas, Easter, and Thanksgiving, customers have ordered Bepang cakes a few days in advance. If a customer orders one week before the "D" day, then there is very little chance of getting it.

Local people's requests for Bepang cake sometimes cannot be fulfilled because the cakes have been bought by regular customers from outside the Langowan area at low prices, then repackaged in better packaging, then sold at a high price. The small industrial business "Kue Bepang Karondoran" in Langowan is managed by the Independent Society Rooted in Society (LM3) GBI Antiokhia Karondoran. The purpose of establishing LM3 is to improve the people's economy. The facts found related to the small industry "Kue Bepang Karondoran" in Langowan show that the production quality of Bepang Cake is still low, the packaging is not attractive, the method of processing Bepang Cake from the past until now is still using simple equipment.

Lembaga Mandiri kepada Masyarakat, 2010).

\section{SOLUTIONS AND OUTSIDE TARGETS}

The solution is to provide counseling and training to partner groups on managing problems in developing Bepang cake products, including counseling and training on: (1) strengthening institutions and members of 
partner groups, namely regarding the functions and roles of leaders and members, communication and quality of relationships between institutional leaders and members. , the relationship between members, as well as a shared perception strategy, (2) product quality improvement strategies, namely facilitating training in business management, administration and finance, (3) product taste strategies, namely providing knowledge about variations in raw materials and processing practices, (4) packaging strategies, namely providing knowledge about packaging requirements, (5) marketing strategies and systems (promotion), (6) analysis of capital and profits, and determination of selling prices, (7) business management, administration and finance, (8) strategies to break through accessibility independently, and (9) facilitate the processing of business permits.

The objectives of managing the Bepang cake products development problem are to improve production quality, accelerate product marketing, and increase group income. That is why this activity is considered very important to carry out. The methods used in the implementation of this activity are the seminar / lecture method, participatory methods, training assistance, monitoring, evaluation of work processes and work results, and reporting.
The outcomes plan for this outreach and training activity is in the form of (1) changes in views and attitudes in dealing with problems in improving the quality of production and development of the Bepang cake business (2) the ability / skills to dialogue in equalizing perceptions to reach an agreement, (3) map of management of business development problems and a roadmap for implementing programs for the development of the Bepang cake business, (4) higher quality products, (5) independent and responsible groups, (6) the family economy of group members increases. (Tanpa Tahun)

\section{METHOD OF IMPLEMENTATION}

(Endah Wulandari , 2017)

The methods used is as follows:

1. Management system counseling, training as a basis for being able to make output as intellectual property rights how to seek innovations to increase the quality of Bepang cake production, including Industrial product design (draft) so that it is feasible to sell at a higher price and how to independently break through the accessibility of marketing at the national level, even global,

2. Outcomes of counseling and training activities: (1) change of views and attitudes in dealing with problems of improving the quality of production 
Jurnal ABDIMAS, Vol. 13, No. 1, April 2020

ISSN: 1979-0953 | e-ISSN: 2598-6066

and business development of the Bepang cake (2) the ability / skills to dialogue in equalizing perceptions to reach an agreement, (3) map of management of business development problems and road maps (roadmap) implementation of Bepang cake business development programs (4) addition of new, higher quality cake / snack products, (5) Improving the quality of Industrial product design technology, so that it is feasible to sell at a higher price and how to break through accessibility independently marketing both at the national and global levels, (5) the Partner group is ready to be independent and responsible, (6) improving agricultural land management technology to produce better quality raw materials for superior products from the Partner group. (7) the family economy of the Partner group members is improving.

3. Monitoring / evaluation of work results in the development of higher quality Kue Bepang product processing and accompanying search for marketing accessibility.

4. Accredited scientific journal publications at the National / International level.

\section{RESULTS AND DISCUSSION}

The Independent Institution Rooted in Society (LM3) GBI Antiokhia does not yet have a complete Bepang cake production process processing equipment. The equipment needed for production processing includes: a large gas stove for cooking rice, cooking / melting palm sugar, frying, rice drying oven, zinc plate which is formed as a container for drying rice for maximum drying, a large frying pan for frying, a large baking sheet as a container. to mix all the raw materials, a large spoon as a tool for frying, mixing and stirring, a blender as a tool for crushing nuts and crushing fruit to extract the juice to produce various fruit flavors from Bepang Cake, a large strainer for draining fried rice crackers, a board container for flattening and slicing of Bepang cake, a large table as a container for placing slicing boards, knives for slicing Bepang cake, quality packaging tools, namely plastic welding tools as an adhesive / pressing tool for packaging, large airtight tupperware / plastic for storage of Bepang cake ready to be marketed, the production label from LM3. The equipment that is not yet in the partner group is: plastic welding equipment, drying oven, quality tupperware / plastic packaging, design of production labels.

The Bepang cake processing partner group still uses an ordinary hock stove, the packaging is still traditional using plastic crackle, the taste is not yet diverse. This kind 
of traditional packaging causes low selling prices and results in limited profits. Access to sales is more limited in the Langowan subdistrict and surrounding sub-districts, if sold outside of North Sulawesi and abroad, only a small portion is from people from Langowan who have moved permanently outside the region and abroad, there is no marketing development outside area legally industry.

The results obtained in this service activity realization are adjusted to the available funds as follows:

Step-I only limited to point one, namely institutional strengthening of group members (LM3) through counseling activities on management systems, training as a basis for being able to make outputs as intellectual property rights how to seek innovations to increase the quality of Bepang Cake production, including Industrial product design (draft) so that it is feasible selling at a higher price and a way to independently break through the accessibility of marketing at the national, even global level.

Step-2 Monitoring / evaluation of work results in the development of higher quality Kue Bepang product processing and accompanying search for marketing accessibility.

Tahapan ke-3 Improving the technology quality of Industrial product design, so that it is feasible to sell at a higher price as well as a way to independently break through better marketing accessibility at the national and global levels. Industrial product design is in accordance with the image below.
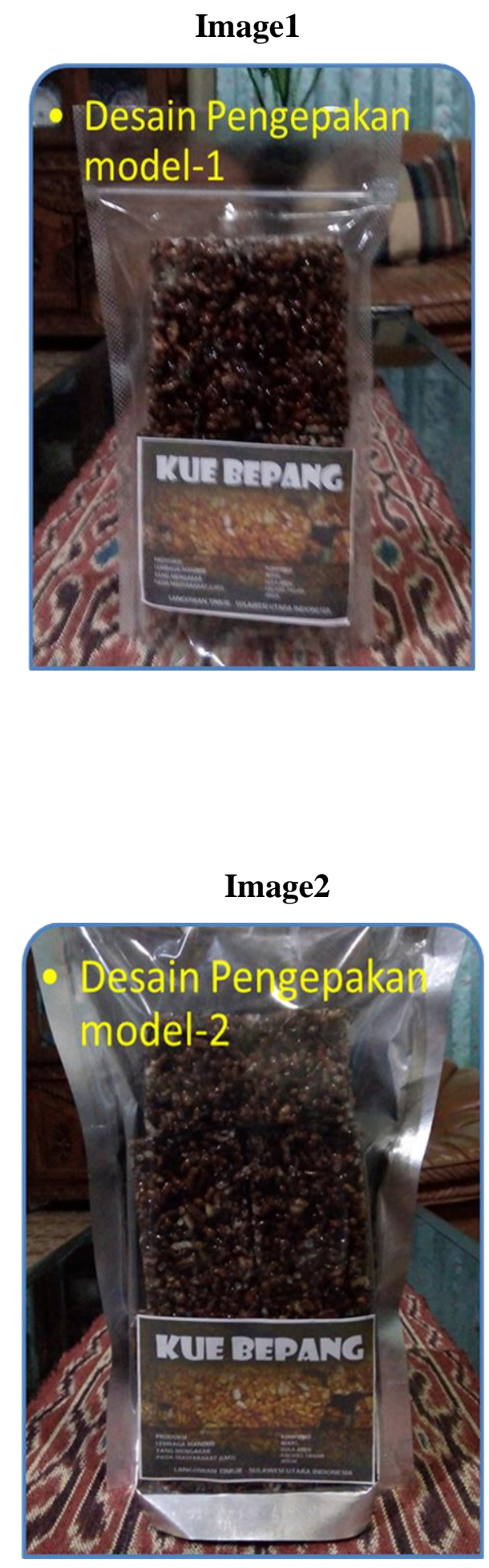
Image-1: Packing Material from

Transparant Plastic

Image-2: Packing Material from Voil Image-3: Packing Material from Brown Plastic

Image3

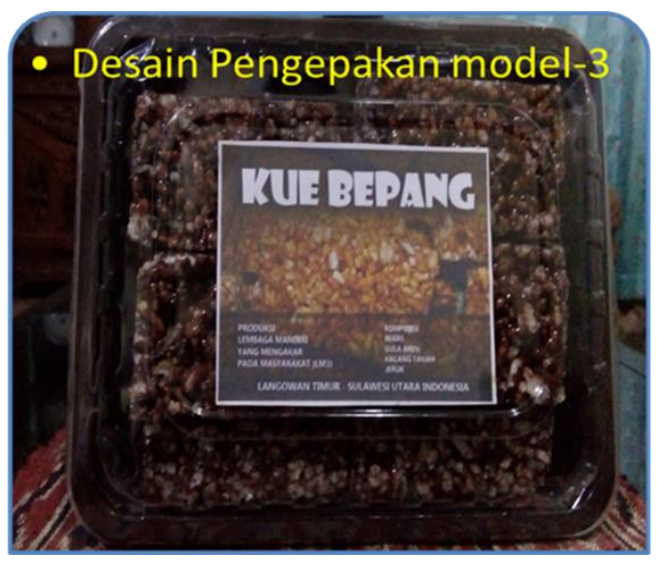

\section{CONCLUSIONS AND ADVICES}

Results in Community Service as follows::

Step-I, institutional strengthening of group members (LM3) through outreach activities on management systems, training as a basis so that groups are able to make outputs as intellectual property rights how to seek innovations to increase the quality of Bepang Cakes production, including industrial product design so that it is feasible to sell at a higher price and how to break through accessibility independently of marketing at the national level, even globally.

Step-2, monitoring / evaluating the results of work in the development of processing of Cakes Bepang products that are of higher quality and accompanying the search for marketing accessibility.

Step-3, improving the quality of technology in the design of industrial products, so that it is feasible to sell at a higher price and how to independently break through better marketing accessibility at the national and global levels.

\section{REFERENCES}

[1] BPS Kabupaten Minahasa, 2017., Minahasa Dalam Angka. Tondano

[2] Lembaga Mandiri kepada Masyarakat, 2010. Laporan Jati Diri Lembaga Mandiri Yang Mengakar Pada Masyarakat. Karondoran

[3] Suoth G.F.E, 2015.,Profil Kota Langowan Beragam Potensi dan Sumberdaya.Panitia Desteny Explotion Gereja Bethel Indonesia Antiokhia Langowa.

[4] Tanpa Tahun., Analisis Potensi Industri Roti Kacang Dalam Pengembangan Wilayah di Kota Tebing Tinggi. Universitas of Sumatera Utara. Institusional Reposito

[5] Endah Wulandari , 2017., SOSIALISASI COOKIES SORGUM SEBAGAI CEMILAN SEHAT DI DESA SAYANG JATINANGOR KABUPATEN SUMEDANG . Dharmakarya: Jurnal Aplikasi Ipteks untuk Masyarakat Vol. 6, No. 3, September 2017: 185 - 188 ISSN 1410 - 5675 . 
Jurnal ABDIMAS, Vol. 13, No. 1, April 2020

ISSN: 1979-0953 | e-ISSN: 2598-6066

Fakultas Teknologi Industri Pertanian

Universitas Padjadjaran E-mail:

endah.wulandari@unpad.ac.id 